\title{
KI A FELELŐS? FELELŐSSÉGI KÉRDÉSEK TISZTÁZÁSA A SZERVEZETEN BELÜLI KARRIERFEJLESZTÉS KAPCSÁN
}

\section{WHO IS IN CHARGE? CLARIFYING RESPONSIBILITIES FOR CAREER DEVELOPMENT WITHIN THE ORGANIZATION}

\author{
Szabó-Bálint Brigitta \\ egyetemi tanársegéd, Pécsi Tudományegyetem Közgazdaságtudományi Kar Vezetés- és Szervezéstudományi Intézet, Pécs \\ balintb@ktk.pte.hu
}

\begin{abstract}
ÖSSZEFOGLALÁS
Jelen tanulmány célja, hogy megválaszolja azt a vitás kérdést, hogy ki a felelős a szervezeten belül a karrierfejlesztésért, és tisztázza az egyéni és a szervezeti oldal felelősségi köreit a folyamatban. Ennek érdekében a szakirodalom és a korábbi kutatások áttekintése mellett a hazai munkavállalók álláspontjának felmérése történik meg. Az eredmények alapján egy ajánlást fogalmaz meg a szerző vezetők és humán erőforrás (HR) szakemberek számára, hogy milyen jellegű szerepet kellene vállalniuk dolgozóik karrierfejlesztésében.

A tanulmány empirikus része egy szervezeti karrierfejlesztési gyakorlatot vizsgáló, munkavállalói oldalt megkérdező, online, ezerfős kutatás eredményein alapul. A kitöltők a versenyszféra fő- és mellékállású dolgozói. A megkérdezett munkavállalók többsége tisztában van azzal, hogy elsősorban az ő kezében van karrierjének alakulása, viszont szüksége van a szervezet segítségére és vezetőjének támogatására is. Az eredmények azt mutatják, hogy többen igényelnének szervezeti együttmúködést a karrierfejlesztés során, mint ahányan kapnak. A munkáltató részéről a közvetlen vezető tekinthető kulcsszereplőnek a munkavállalók karrierfejlesztésében, és kisebb szerepet tulajdonítanak a megkérdezettek a HR-es kollégáknak. Érdekesség, hogy a felső vezetőktől sokkal több támogatást várnának el a dolgozók, mint a HR-részlegtől.

Az eredmények alapján elmondható, hogy az egyén tekinthető elsősorban felelősnek karrierjének fejlesztéséért, de szükség van a szervezeti oldal aktív részvételére is, a vezetőnek kell irányítania, terelgetnie a dolgozót az olyan karrierlehetőségek felé, amelyek a szervezeti és az egyéni célok megvalósulását is támogatják.
\end{abstract}

\section{ABSTRACT}

The scope of this study is to answer that controversial question who is responsible for career development within the organization, and clarify the responsibilities of the individual and the organizational side in the process. For this reason, besides reviewing the literature and previous researches, the assessment of the opinion of domestic workers will be carried out. Recommendation will be defined to managers and human resource (HR) professionals, based on the review of the literature and research results, on the kind of role they should play in the career development of their employees. 
The empirical part of the study is based on the results of an online research which surveyed 1000 employees and examined organizational career development practices. The respondents are full and part time employees in the private sector. The majority of the surveyed workers are aware of the fact that their career depends on them but they need the help of the organization and the support of their manager. The results show that more people would require organizational cooperation during career development than who are actually given. The direct manager can be considered a key player in the career development process of employees from the employer side and the role of the HR professionals is less important. Interestingly, workers would expect much more support from senior executives than from the HR department.

Based on the findings, it should be admitted that the individual can be considered to be primarily responsible for the development of his or her career but the active involvement of the organization is also needed. The manager is to sway the employee towards career opportunities that support the achievement of organizational and individual goals, too.

Kulcsszavak: karrier, karrierfejlesztés, felelősség, munkavállalók, vezető

Keywords: career, career development, responsibility, employees, manager

\section{BEVEZETÉS}

Az új karrierkoncepciók, a határváltó vagy a formaváltó karrier, az egyén kezébe teszik karrierjének irányítását, szemben a tradicionális modellel, amelyben a szervezet volt a felelős a karrierfejlesztésért - állítja Yehuda Baruch (2004) cikkében. Robert J. DeFillippi és Michael B. Arthur (1996) alapján a határváltó karrier alatt olyan munkalehetőségek sorozatát értjük, amelyek túlmutatnak egyetlen szervezet határain, azaz több munkáltatónál valósítható meg karrier, nem egyetlen vállalathoz kötött. A másik új típusú karrier pedig a formaváltó (protean) karrier, amely Michael B. Arthur (1994) szerint az életpálya változatosságára fókuszál. Ezt a típust önállóan irányítottként és értékvezéreltként jellemzik, amely John Arnold (2011) olvasatában azt jelenti, hogy az egyén felelős karrierjéért, és képes is azt irányítani a számára fontos értékek mentén. Ezek a karrierfogalmak az egyéntől követelik meg az aktív szerepvállalást a saját karrier fejlesztése kapcsán. Köszönhetően ennek, és a megváltozott munkaadó-munkavállalói viszonynak, a szervezetek inkább visszavonultak a karrierfejlesztési tevékenységböl. A munkáltatóknak azonban nem szabadna háttérbe húzódniuk, nélkülük nem valósítható meg sikeres karrierfejlesztés. A karrierfejlesztésért való felelősség Natalie Lam és szerzőtársai (1999) szerint három fél között oszlik meg: az egyén, a vezető és a szervezet. Az egyénnek kell elsődlegesen felelnie karrierjéért, a vezetőnek kell támogatnia és mentorálnia a megfeleló irányba (például a szervezet által kívánatos pozíció felé), a szervezetnek pedig lehetőséget kell teremtenie és erőforrásokat biztosítania a tanulásra és a fejlődésre. 
Jelen tanulmány célja, hogy feloldja ezt a vitás kérdést, hogy kinek kellene aktívabban részt vennie a karrierfejlesztési tevékenységben, és tisztázza az egyén és a szervezeti oldal felelősségi köreit a folyamatban egyrészt a szakirodalom, másrészt a hazai munkavállalók álláspontjának felmérése alapján.

\section{SZERVEZETI KARRIERFEJLESZTÉS}

A szakirodalom alapján elsőként ismertetem a szervezeti karrierfejlesztés fogalmát és a célját, majd bemutatom a folyamat szereplőit, végül tisztázom az egyes résztvevők feladatait és felelősségi köreit.

\subsection{A szervezeti karrierfejlesztés fogalma és célja}

Lesley E. Armstrong (1992) a karrierfejlesztést két különálló, de egymással öszszefüggő funkciók együtteseként értelmezi Walter D. Storey (1976), valamint Douglas T. Hall és szerzőtársai (1986) alapján:

- az egyik a karriertervezés, amely magában foglalja azokat a magatartásokat és attitűdöket, amelyeket az egyén felvállal és felelösséggel viseltet irántuk,

- a másik pedig a karriermenedzsment - amely egy intézményi folyamatnak tekinthetö, amely az egyén által egyedül vagy a szervezettel közösen készített karriertervek létrehozását, megvalósítását és nyomon követését jelenti (Storey, 1976; Hall et al., 1986 - idézi: Armstrong, 1992).

Yehuda Baruch és Pawan S. Budhwar (2006) bár rövidebben fogalmaznak, de szintén rendszerben gondolkodnak a fogalmak kapcsán. A karrier tervezésére és menedzselésére együttesen, átfogó rendszerként tekintenek, amely magában foglal minden olyan tevékenységet és technikát, amellyel a szervezet elősegíti a munkavállalók karrierfejlesztését. Azt mondhatjuk, hogy a rendszer eredménye lesz a karrierfejlesztés.

Gary D. Gottfredson (2005) úgy látja, hogy a szervezeti karrierfejlesztési tevékenységek elsősorban a szervezet érdekeit szolgálják, és másodsorban segítik alkalmazottai karriercéljainak elérését. Jane Yarnall (2008) többek között olyan célokat fogalmaz meg egy karrierfejlesztési rendszer kapcsán, mint a szervezet jövőre való felkészítése azáltal, hogy a munkavállalói képességeket úgy fejleszti, hogy azok támogassák a hosszú távú üzleti stratégia megvalósulását, vagy az üzleti igények rugalmas kielégítésének biztosítása azáltal, hogy tehetségbázist hoz létre és fejleszt a szervezeten belül, illetve az alkalmazotti morál és motiváció növelése a nagyobb elköteleződés érdekében. Peter Creed és Michelle Hood (2009) az előzőekhez hasonlóan fejtik ki, hogy a szervezetek további célja, hogy a kiváló és a kritikus tudással rendelkező munkavállalóikat megtartsák, ezért a szervezeti 
célokhoz igyekeznek hozzáigazítani ezeknek a munkavállalóknak a karrierútjait, ezzel is erősítve szervezethez kötődésüket.

Összességében az látható, hogy a karrierfejlesztési gyakorlat elsődleges célja a szervezet érdekeinek megfelelő tudású és motivációjú munkavállalók biztosítása, és másodlagos célja a munkavállalók igényeit is figyelembevevő karrierfejlesztési tevékenység megvalósítása.

\subsection{A karrierfejlesztési gyakorlat szereplői és felelősségi körük}

A szervezeti karrierfejlesztési gyakorlatban az egyik fontos szereplő a munkavállaló maga, további lényeges közremüködő a vezetés (mind a közvetlen felettes, mind a felsőbb vezetők), valamint a HR-részleg.

\subsubsection{A karrierfejlesztési folyamat résztvevői}

A szervezeti karriermenedzsment rendszer müködtetéséhez Koncz Katalin szerint (2004) mindenekelőtt szükség van egy felkészült HR szervezeti egységre, amely hatékony emberierőforrás-menedzsment gyakorlatot folytat. Wendy Hirsh és Charles Jackson (2004) azt is kifejtik, hogy a HR-nek olyan kulcsfeladatai vannak a karrierfejlesztés folyamatában, mint hogy együtt kell dolgozniuk a vezetőkkel a karrierfejlesztési stratégia és a folyamatok formálásán, valamint ezeknek a dolgozók felé történő kommunikációján. Általános információkat kell nyújtaniuk a szervezeti munkakörökröl, karrierutakról. Információkat gyüjtenek, kezelnek a kollektív vállalati karrierfolyamatokhoz (például utódlástervezés). Támogatják a karrierfejlesztési programokat, párbeszédet folytatnak a rendszer résztvevőivel, valamint biztosítják, hogy a vezetők rendelkezzenek a kritikus készségekkel a karrierfejlesztéshez. Kiemelik továbbá, hogy a munkavállalók és a vezetők elvárják a HR-részlegtől, hogy megbízható, hasznos, értelmes karriertanácsokat adjanak.

Koncz (2004) szerint a karriertámogatás vezetöi funkció is egyben, mivel a vezetö érdeke is, hogy a részlegén belül a különböző munkaköröket a legmegfelelőbb emberek töltsék be. Ezért a felső vezetés támogatása, a vezetők közremüködése is fontos momentum a sikeres szervezeti karriermenedzsmentben, hiszen motiváló hatással lehet a beosztottakra, ha látják, hogy vezetőjük elkötelezett a rendszer iránt. Optimális esetben a közvetlen munkahelyi vezető és a HR-rel foglalkozó vezető együtt tervezi meg a szervezeti karriergondozási rendszert. Megfigyelhetö, hogy a folyamatban bizonyos felelösségi körök, amelyek sokáig a HR-hez tartoztak, egyre inkább a vonalbeli vezetőkhöz kerülnek át - állítja Baruch (2004). Gondolhatunk itt például a karrierkonzultációra. Belegondolva abba, hogy a közvetlen felettesek nap mint nap együtt dolgoznak beosztottjaikkal, jobban ismerik őket, valamint a szervezeti lehetőségekről is bővebb információkkal rendelkeznek, belátható, hogy ők hatékonyabban képesek ellátni ezeket a karrierfejlesztési feladatokat. Viszont egyes tanulmányok (például: Elissa L. Perry és 
Carol T. Kulik 2008-as cikke) rámutatnak, hogy a vezetők erre még nincsenek felkészülve, nem rendelkeznek megfelelő tudással vagy kompetenciákkal ehhez.

A hatékony karrierfejlesztési gyakorlathoz szükséges továbbá, hogy a dolgozók is elkötelezettek legyenek, és aktív szerepet vállaljanak a karrierfejlesztés folyamatában. „Olyan magatartás kívánatos, amely előtérbe helyezi a saját szakmai önfejlesztést" - állítja Vitár Zoltán (1996, 30.). Denise M. Rousseau (2005) szerint a munkavállalók proaktívabbak karrierjük építésében, mint korábban a tradicionális karrier időszakában. Egyéni tárgyalásokat folytatnak munkaadóikkal karrierjük érdekében, és egyéni üzleteket kötnek, amelyek Denise M. Bal és szerzőtársai (2012) szerint egyéni fejlődési lehetőségeket és sajátos karrierállomásokat tartalmazhatnak.

\subsubsection{Ki a felelös a karrierfejlesztésért?}

Gyakran vitatott kérdés, hogy ki felel a karrier fejlesztéséért. Az 1950-es években főként úgy tekintettek rá, mint amiért a szervezet a felelős. Az 1990-es években más vélemény kezdett uralkodóvá válni, mely szerint az egyének vették kezükbe az irányítást - foglalja össze Douglas T. Hall (1996). Bizonyos írások úgy, mint Michael B. Arthur és szerzőtársai (1995) tanulmánya, az egyéni dominancia mellett megemlítik az egyén és a szervezet közös felelösségét is. Bár megfigyelhető kutatásokból, hogy a munkavállalók egyre inkább saját maguk vállalnak felelősséget karrierjükért, Marjolein Lips-Wiersma és Douglas T. Hall (2007) úgy tapasztalták, hogy a legtöbb dolgozó még mindig elvárja a segítséget a munkahelyétôl. Tanulmányukban egy olyan szervezet példáját vizsgálták, amelyben szervezetistruktúra-átalakítás ment végbe (egy laposabb, decentralizáltabb struktúrát hoztak létre). Azt tanulmányozták, vajon az új müködési környezetben több felelősséget vállalnak-e a munkavállalók karrierjükért, és ezzel egy időben a szervezet háttérbe vonul-e. Azt találták, hogy a munkavállalók valóban több felelősséget vállaltak a változásokat követően. (Megjegyzendő, hogy a szervezet erre folyamatosan igyekezett fel is készíteni az alkalmazottakat.) Viszont ezzel egy időben nem vonult teljesen háttérbe a munkáltató, hanem bizonyos karrierfejlesztési folyamatokban továbbra is részt vett. Nem müködött az, ha teljesen kimaradt a karriertevékenységekből, továbbra is kellett az iránymutatás, a segítség az alkalmazottaknak.

Jonathan R. Crawshaw és Annilee M. Game (2015) kutatásukban szintén arra jutottak, hogy a munkavállalók úgy gondolják, hogy a karriermenedzsment folyamatokban a vonalbeli vezetők a szervezet kulcsfontosságú képviselői. Ahol gondozó, szorosabb kapcsolatot alakítottak ki dolgozóikkal, ott az érintettek egy olyan biztonságos alapot érzékeltek, amelyre támaszkodhatnak karrierjük menedzselése közben. A negatív tapasztalattal rendelkező munkavállalók arról számoltak be, hogy vezetőjük túl elfoglalt, hogy karrierjük fejlesztésében segítse őket, vagy nem veszi figyelembe az igényeiket. 
Hazai tekintetben Bokor Attila és munkatársai (2006) karriermenedzsment témájú kutatását érdemes megemlíteni, amely során érintették a felelősség kérdését is. Azt tapasztalták, hogy ez az ellentmondás fennáll a hazai vállalatoknál is. A HR-es kollégák fontosnak tartják, hogy a dolgozók maguk tervezzék a karrierjüket, legyenek konkrét céljaik, és tegyenek is érte, hogy azokat elérjék. Ezzel ellentétben vannak olyan szervezetek, ahol viszont gyanús, ha a munkatárs túl sokat törődik karrierjével. Az ilyen cégek szemében megkérdőjeleződik az alkalmazott munkateljesítménye és akár a hüsége is.

Összegezve az elmondottakat úgy gondolom, hogy valóban az egyén tekinthető elsősorban felelősnek karrierjének fejlesztéséért, de szervezeti karriergondozási gyakorlatról lévén szó, amelynek egyik elsődleges célja a szervezeti igények kielégítése, el kell ismerni, hogy a szervezetnek továbbra is meghatározó szerepet kell vállalnia a folyamatban. A munkavállalótól nem várható el teljes mértékben, hogy a szervezeti céloknak megfelelően cselekedjen. Ehhez szükség van a szervezeti oldal aktív részvételére is, aki irányítja, terelgeti a dolgozót az elérhető karrierlehetőségek (például: elérhető pozíciókkal, fejlődési vagy tapasztalatszerzési lehetőségekkel) tisztázásával, megismerési lehetőségük biztosításával.

\section{KUTATÁS ISMERTETÉSE}

Mivel hazai viszonylatban nem állnak rendelkezésre aktuális adatok, fel kívántam mérni, hogy a magyar dolgozók hogyan gondolkodnak a felelősség kérdésében, illetve hogyan érzékelik, mennyire aktív a munkáltatójuk a karriertámogatás terén. A felmérésem adatait egy szervezeti karrierfejlesztési gyakorlatot vizsgáló, munkavállalókat megkérdező, online, ezerfős kutatás részeredményei szolgáltatják, amely az EFOP-3.6.3-VEKOP-16-2017-00007 kódszámú pályázat támogatásával valósult meg. A kitöltők a versenyszféra fö- és mellékállású dolgozói. Az adatok SPSS-programmal kerültek vizsgálatra. Gyakorisági lekérdezéseket, kereszttábla-elemzéseket és kapcsolatvizsgálatokat végeztem.

\subsection{Kutatási eredmények}

A minta reprezentatív kor, nem, képzettség és lakhely szerint. Az alapvető demográfiai és munkahellyel kapcsolatos adatok kapcsán a következők mondhatók el: A kitöltők jelentős többsége férfi (64\%), a felmérésben részt vevők átlagéletkora 42 év. A legtöbben (75\%) középfokú végzettséggel rendelkeznek. A megkérdezettek 94\%-a föállású alkalmazott. Az ágazatot tekintve a legtöbben a következő öt kategóriában dolgoznak: feldolgozóipar, egyéb szolgáltatás, kereskedelem és gépjármüjavítás, építőipar, valamint információ és kommunikáció. A kitöltők többsége beosztottként dolgozik (83\%) többnyire kis- és 
középvállalkozásoknál (60\%). A munkáltatók több mint fele (56\%) magyar tulajdonban van.

A minta alapjellemzőinek bemutatása után a tanulmány témája szempontjából releváns kérdések kerülnek kiértékelésre a következő alfejezetben.

\subsubsection{Ki mennyiben felelös?}

A válaszadók általában úgy gondolják, hogy nagyobb részt (67\%-ban) ők a felelősek karrierjükért, míg kis részben (33\%-ban) a szervezetnek is tulajdonítanak felelösségi szerepet karrierjük fejlesztése kapcsán. Az 1. ábra mutatja, hogyan oszlanak meg pontosan az egyes felelősségi kategóriák a munkavállalók válaszai alapján.

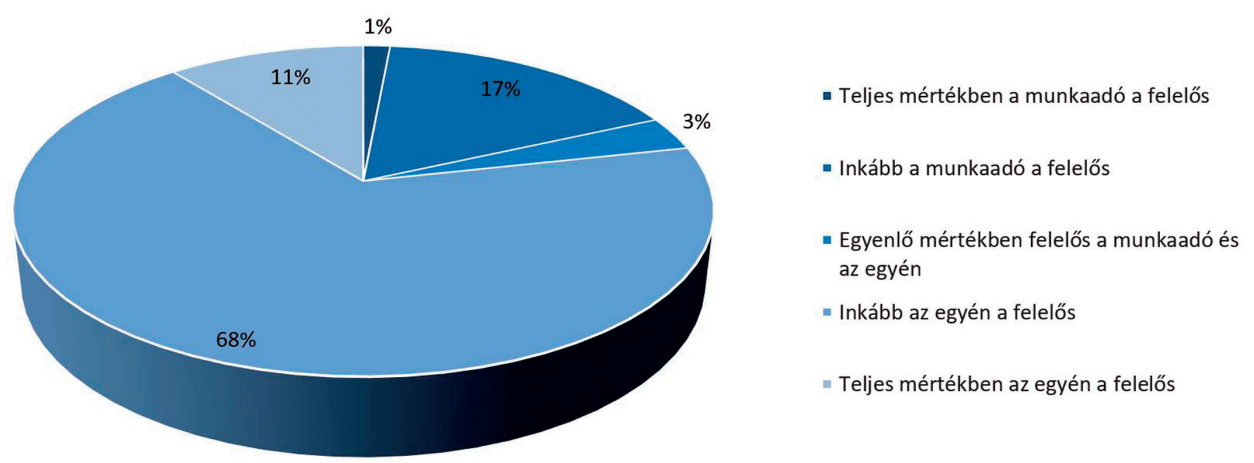

1. ábra. A felelősség mértékének megoszlása a karrierfejlesztés során (Az ábrák a szerző saját szerkesztései)

A megkérdezettek nagyon kis hányada (1\%) szerint a munkaadójuk felelös teljes mértékben a karrier fejlesztéséért. A legtöbben (68\%) úgy gondolják, hogy inkább az ő kezükben van karrierjük sorsa, de a szervezetnek is van befolyása rá. A válaszokból tehát az látszik, hogy a munkavállalók döntő többsége úgy véli, hogy elsősorban ő felel karrierje fejlesztéséért, de a szervezetnek is fontos szerepe van annak alakulásában.

\subsubsection{Segitség igénylése, tényleges részesülés benne}

A karrierfejlesztéshez nyújtott támogatás elvárására vonatkozó kérdés egy öszszetett kérdés volt, amelynek az első fele arra vonatkozott, hogy a munkavállaló igényel-e segítséget karrierjének fejlesztéséhez, a második fele pedig arra, hogy ténylegesen megkapja-e. A munkavállalók 53\%-a elvárná a segítséget karrierje fejlesztéséhez, azonban közülük csak $40 \%$ kap ténylegesen is támogatást, ami az összes megkérdezett dolgozó 21\%-a. Az eredményeket a 2. ábra mutatja. 


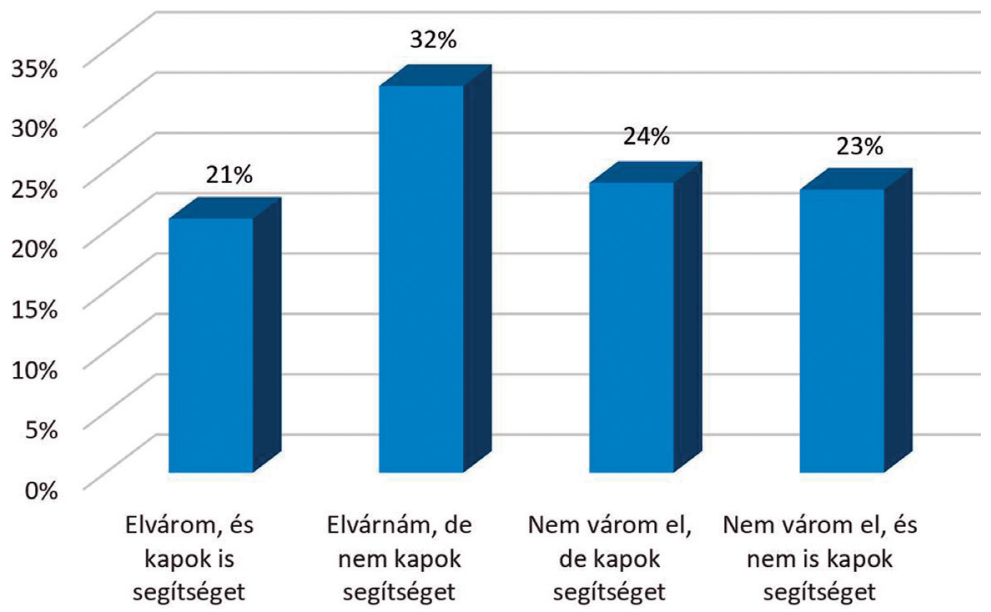

2. ábra. Elvárt, illetve tényleges karrierfejlesztési segítség megoszlása

Az eredmények alapján megfogalmazható, hogy a hazai munkavállalók többsége számít a szervezet aktív részvételére és támogatására is.

A felelősségvállalás mértéke és az elvárt segítség összehasonlítása kapcsán az látszik az eredményekből (1. táblázat), hogy akik a szervezetet tekintik inkább (17\%) vagy teljes mértékben (1\%) felelősnek a karrierfejlesztés során, azok többsége (78\%, illetve 54\%) elvárja, hogy a munkaadó segítse őket karrierjük során. Szintén ez az elvárás azon munkavállalók többségénél (55\%) is, akik inkább magukat tekinti felelősnek karrierjüket illetően (68\%). Akik teljes mértékben magukat tekintik számon kérhetőnek életpályájuk irányítása kapcsán, azoknak a nagyobb hányada (57\%) nem vár el segítséget a munkáltatótól.

1. táblázat. A felelősség mértékének megoszlása a karrierfejlesztés során és azzal összefüggésben a szervezettől segítőt elvárók arányának megoszlása

\begin{tabular}{|l|c|c|}
\hline \multicolumn{1}{|c|}{ Felelősség megoszlása } & $\begin{array}{c}\text { Válaszadók } \\
\text { aránya }\end{array}$ & $\begin{array}{c}\text { Közülük hányan várnak } \\
\text { a szervezettôl segítséget }\end{array}$ \\
\hline Teljes mértékben a munkaadó a felelős & $1 \%$ & $78 \%$ \\
Inkább a munkaadó a felelős & $17 \%$ & $54 \%$ \\
Egyenlő mértékben felelős a munkaadó és az egyén & $3 \%$ & $48 \%$ \\
Inkább saját magam vagyok felelős & $68 \%$ & $55 \%$ \\
Teljes mértékben az egyén a felelős & $11 \%$ & $43 \%$ \\
\hline
\end{tabular}


A két kérdés között szignifikáns kapcsolat van, amelyet az egyutas varianciaanalízis mutatott ki $(\mathrm{p}<0,01 ; \mathrm{F}=20,145)$. A 3. ábrán látható az elemzés eredménye, amely szerint, aki kap a munkaadójától segítséget karrierfejlesztéséhez, nagyobb mértékben tekinti saját magát felelősnek karrierjéért, mint aki nem kap.

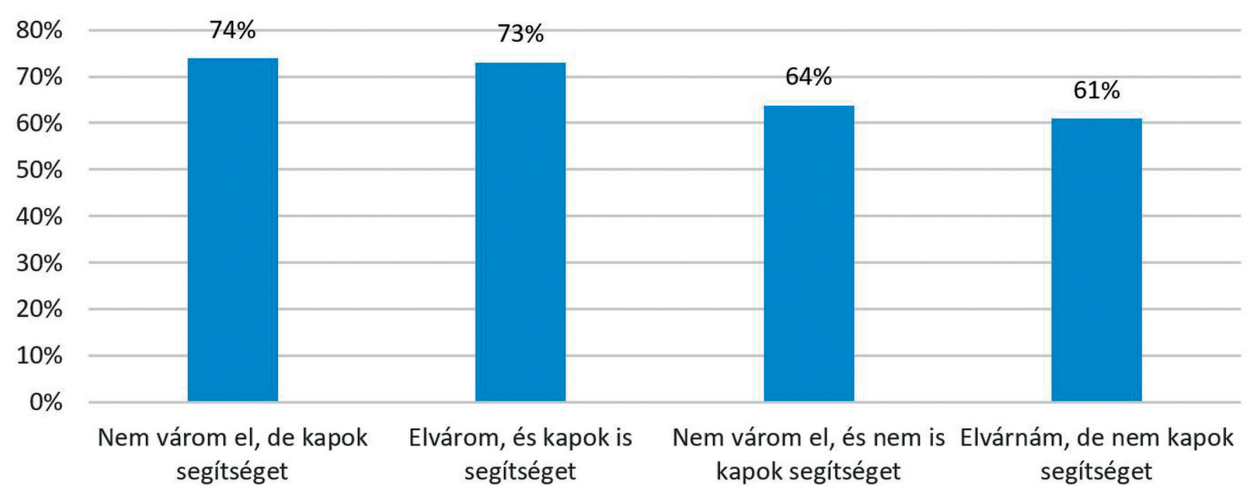

3. ábra. A karrierfejlesztés kapcsán elvárt és ténylegesen kapott, valamint a saját karrierért érzett felelősség mértékének összefüggése

Továbbá felmértük azt is, hogy a munkavállalók mely szervezeti szereplőktől várnak el és kapnak támogatást karrierjük fejlesztése során. A kitöltőknek pontosan 100 pontot kellett elosztani a különböző szereplök között, aszerint, hogy kitöl milyen mértékü segítséget vártak el karrierjük előmozdítása érdekében, illetve ténylegesen mennyi segítséget kapnak tölük. Az eredmények a 4. ábrán látható diagramon olvashatók.

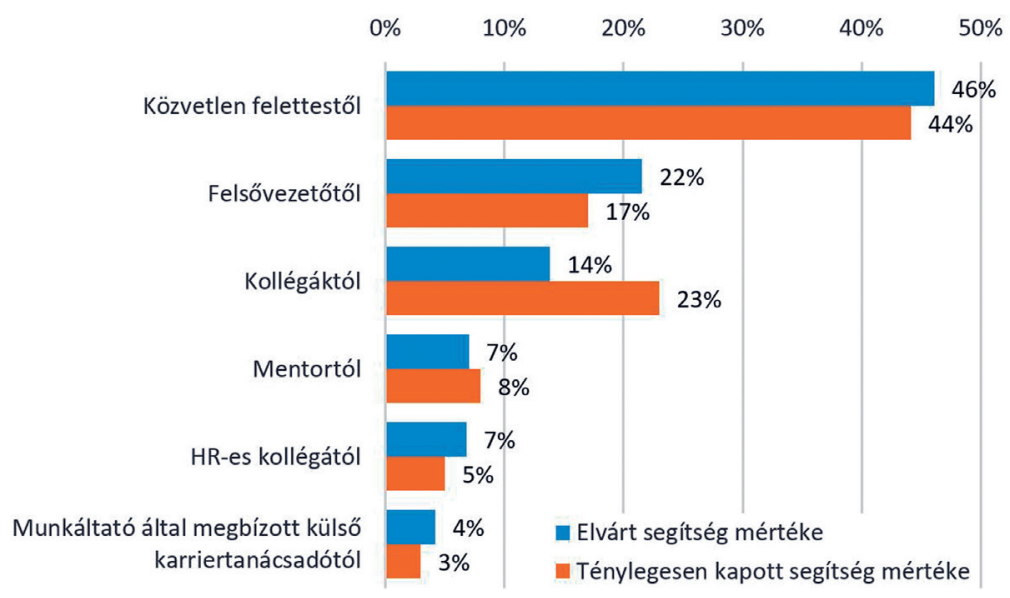

4. ábra. A különböző szervezeti szereplőktől elvárt és ténylegesen kapott karrierfejlesztési segítség megoszlása 
A vezetök (közvetlen és felsö) és a HR-es kolléga kapcsán is az látható, hogy némileg több segítséget $(46 \% ; 22 \%$, valamint $7 \%)$ várnának el a munkavállalók, mint amennyit kapnak (44\%; 17\%, valamint 5\%). Érdekes eredmény, hogy a kollégáktól kapott segítség is jelentős mértékủ (23\%), viszont ennél kevesebbet igényelnének a kitöltők (14\%). Valószínűleg az előbb említett három szereplőtől várnának helyettük több támogatást. A mentoroknak is némileg kisebb szerepet szánnának a dolgozók (7\%), mint amekkora most jut nekik (8\%). Összességében az látható, hogy többnyire azoktól kapnak segítséget a munkavállalók, akiktől elvárnák karrierjük menedzselése során, csupán egyes szereplök esetén, mint például a vezetők és a HR-es kolléga, kicsivel nagyobb mértékben igényelnék ezt. Az eredmények összecsengenek a szakirodalommal, azaz valóban a közvetlen vezetö tekinthető kulcsszereplőnek a munkavállalók karrierfejlesztésében, és kisebb szerepet tulajdonítanak a munkavállalók a HR-es kollégáknak. Érdekesség, hogy a felső vezetőktől sokkal több támogatást várnának el a dolgozók, mint a HR-részlegtől.

\section{KONKLÚZIÓ}

Jelen tanulmány célja az volt, hogy feloldja azt a vitás kérdést, hogy ki a felelős a szervezeten belül a karrierfejlesztésért. Ennek érdekében felmérte a hazai munkavállalók álláspontját a kérdést illetően. A szakirodalommal összhangban a kutatási eredmények alapján is az látható, hogy a hatékony karrierfejlesztési tevékenység megvalósulásához valóban három fontos föszereplő azonosítható be: a munkavállaló, a közvetlen felettese és a szervezet. Mindhárom résztvevő esetén az egyik legfontosabb tényezö a folyamat iránti megfelelö mértékủ elkötelezettség megléte. A szervezetre tekinthetünk gyüjtőkategóriaként, amihez hozzátartozik a felső vezetés, amely a müködési kereteket szabja, és a feltételeket (például: pénzbeli, eszközbeli) biztosítja, valamint a HR-munkatársak, akiknek pedig egyfajta támogató, információmegosztó szerepük van. Emellett a dolgozónak tisztában kell lennie saját céljaival, szükségleteivel és kompetenciáival, valamint egyfajta proaktív módon neki kell a fejlődési és tapasztalatszerzési lehetőségeket keresnie. Végül pedig a közvetlen felettes játszik kiemelt szerepet a folyamatban, hiszen ö ismeri beosztottját és a szervezeti lehetőségeket is, az ö felelössége, hogy a munkavállaló és a szervezet igényei közti összhangot megteremtse. Persze ez nem könnyü feladat, nem árt némi érzék, illetve képzettség is hozzá, és a sok vezetői teendő mellett időt is kell rá találni. A megkérdezett munkavállalók többsége tisztában is van azzal, hogy elsősorban a saját kezében van karrierjének alakulása, viszont szüksége van a szervezet segítségére is, vezetőjének támogatására is. Az eredmények azt mutatják, hogy többen igényelnének szervezeti együttmüködést a karrierfejlesztés során, mint ahányan kapnak. 
Végül pedig válaszolva a címben szereplő kérdésre, hogy ki a felelős a szervezeten belüli karrierfejlesztésért, az az álláspontom, hogy elsősorban az egyén tekinthető felelősnek karrierjének fejlesztéséért - még a szervezeten belül is, de szervezeti gyakorlatról lévén szó, a munkáltatónak is aktívan részt kell benne vennie, hogy a dolgozó a szervezeti céloknak megfelelően cselekedjen. Ezt pedig úgy érheti el, ha olyan karrierlehetőségeket és feltételeket teremt (például: elérhető pozíciók, fejlődési vagy tapasztalatszerzési lehetőségek), amelyek mind a két fél érdekeit szolgálják.

A tanulmány az Emberi Erőforrások Minisztériuma ÚNKP-18-3 kódszámú Új Nemzeti Kiválóság Programjának támogatásával készült.

\section{IRODALOM}

Armstrong, L. E. (1992): Organisational Career Development Programs and Practices: Emerging Issues for Careers Practitioners, Managers and Employees. Australian Journal of Career Development, 1, 1, 29-33. DOI: 10.1177/103841629200100109

Arnold, J. (2011): Career Concepts in the $21^{\text {st }}$ Century. The Psychologist, 24, 2, 106-109. https:// pdfs.semanticscholar.org/6de4/6e7daf145368d3c44ca805d8d38e34096744.pdf

Arthur, M. B. (1994): The Boundaryless Career: A New Perspective for Organizational Inquiry. Journal of Organizational Behavior, 15, 4, 295-306. DOI: 10.1002/job.4030150402

Arthur, M. B. - Claman, P. H. - DeFillippi, R. J. (1995): Intelligent Enterprise, Intelligent Careers. Academy of Management Executive, 9, 4, 7-22. https://www.jstor.org/stable/4165285?seq=1\#page_scan_tab_contents

Bal, P. M. - De Jong, S. B. - Jansen, P. G. W. et al. (2012): Motivating Employees to Work beyond Retirement: A Multi-level Study of the Role of I-Deals and Unit Climate. Journal of Management Studies, 49, 2, 306-331. DOI: 10.1111/j.1467-6486.2011.01026.x, https://bit. ly/2IKaG3a

Baruch, Y. (2004): Trans Forming Careers: From Linear to Multidirectional Career Paths. Organizational and Individual Perspectives. Career Development International, 9, 1, 58-73. https:// bit.ly/2OJfv0r

Baruch, Y. - Budhwar, P. S. (2006): A Comparative Study of Career Practices for Management Staff in Britain and India. International Business Review, 15, 1, 84-101. DOI: 10.1016/j.ibusrev.2005.11.001, https://www.researchgate.net/publication/227417264_A_comparative_study_ of_career_practices_for_management_staff_in_Britain_and_India

Bokor A. - Fejér P. - Frisch A. et al. (2006): Karriermenedzsment Magyarországon. A HR-vezetők nézőpontja (III. rész). Munkaügyi szemle, 50, 12, 11-14.

Crawshaw, J. R. - Game, A. M. (2015): The Role of Line Managers in Employee Career Management: An Attachment Theory Perspective. International Journal of Human Resource Management, 26, 9, 1182-1203. DOI: 10.1080/09585192.2014.934886, https://bit.ly/2OITVJj

Creed, P. - Hood, M. (2009): Career Development, Planning and Management from the Organisational Perspective. In: Collin, A. - Patton, W.: Vocational Psychological and Organisational Perspectives on Career: Towards a Multidisciplinary Dialogue. Rotterdam, The 
Netherlands: Sense Publications, 41-62. https://research-repository.griffith.edu.au/handle/10072/30037

DeFillippi, R. J. - Arthur, M. B. (1996): Boundaryless Contexts and Careers: A Competency-based Perspective. In: Arthur, M. B. - Rousseau, D. M. (eds.): The Boundaryless Career: A New Employment Principle for a New Organizational Era. New York: Oxford University Press, 116-131. DOI: 10.1002/job.4030150403, https://www.researchgate.net/publication/242506242 Boundaryless_contexts_and_careers_a_competency-based_perspective

Gottfredson, G. D. (2005): Career Development in Organizations. In: Walsh, W. Bruce - Savickas, Mark L. (Eds.): Contemporary Topics in Vocational Psychology. Handbook of Vocational Psychology: Theory, Research, and Practice. Mahwah, NJ: Lawrence Erlbaum Associates Publishers, 297-317.

Hall, D. T. (1996): The Career Is Dead - Long Live the Career. San Francisco: Jossey-Bass

Hall, D. T. and Associates (eds.) (1986): Career Development in Organisations. San Francisco: Jossey-Bass

Hirsh, W. - Jackson, C. (2004): Managing Careers in Large Organisations. London: The Work Foundation, https://www.researchgate.net/publication/237414670_Managing_Careers_in_Large_ Organisations

Koncz K. (2004): Karriermenedzsment. Budapest: Aula Kiadó

Lam, N. - Dyke, L. - Duxbury, L. (1999): Career Development in Best-practice Organizations: Critical Success Factors. Optimum. The Journal of Public Sector Management, 29, 4, 22-30. http://www.aijssnet.com/journals/Vol_3_No_7_December_2014/8.pdf

Lips-Wiersma, M. - Hall, D. T. (2007): Organizational Career Development Is Not Dead: A Case Study on Managing the New Career during Organizational Change. Journal of Organizational Behavior, 28, 6, 771-792. https://bit.ly/2IN3tz5

Perry, E. L. - Kulik, C. T. (2008): The Devolution of HR to the Line: Implications for Perceptions of People Management Effectiveness. International Journal of Human Resource Management, 19, 2, 262-273. DOI: 10.1080/09585190701799838, https://bit.ly/2MFZAxd

Rousseau, D. M. (2005): I-Deals: Idiosyncratic Deals Employees Bargain for Themselves. New York: M. E. Sharpe

Storey, W. D. (ed.) (1976): A Guide for Career Development Inquiry: State-of-the-Art Report on Career Development. (ASTD Research Series Paper No. 2) Madison, WI: American Society for Training and Development

Vitár Z. (1996): A munkáltató és a munkavállaló lehetőségei egy Karrier Támogató Rendszer (KTR) müködése esetén. Munkaügyi szemle, 40, 4, 30-32.

Yarnall, J. (2008): Strategic Career Management: Developing Your Talent. Oxford: ButterworthHeinemann 